\title{
INFEKSI PENYAKIT IKAN BANGGAI CARDINAL (Pterapogon kauderni) DALAM RANTAI PERDAGANGAN
}

\author{
Devita Tetra Adriany ${ }^{* * *}$ dan Isti Koesharyani**) \\ ${ }^{*}$ Karantina Ikan Pengendalian Mutu dan Keamanan Hasil Perikanan Kelas II Luwuk Banggai, Sulawesi Tengah \\ *) Pusat Riset Perikanan Budidaya
}

(Naskah diterima: 17 Juli 2017; Revisi final: 30 November 2017; Disetujui publikasi: 30 November 2017)

\begin{abstract}
ABSTRAK
Banggai cardinal (Pterapogon kauderni) merupakan ikan hias endemik dari perairan Kepulauan Banggai, Sulawesi Tengah dan mulai dieksploitasi sejak tahun 1980. Ikan hias ini banyak diekspor ke berbagai negara. Namun, dengan banyaknya kasus infeksi penyakit seperti bakteri dan virus Banggai Cardinal Iridovirus (BCIV), sehingga permintaan ikan hias asal Indonesia ini menurun. Tujuan penelitian ini adalah untuk menelusuri dan menginventarisasi alur kejadian infeksi penyakit pada rantai perdagangan ikan hias Banggai Cardinal mulai dari hasil tangkapan nelayan, pengumpul, dan eksportir. Analisis dilakukan dengan mengambil sampel ikan masing-masing 15 ekor dari setiap rantai perdagangan. Pengamatan yang dilakukan meliputi pemeriksaan parasit, jamur, bakteri, dan analisis virus BCIV. Hasil yang diperoleh menunjukkan bahwa sampel ikan dari semua rantai perdagangan nelayan penangkap, pengumpul, dan eksportir tidak ditemukan infeksi parasit dan jamur. Sementara, pada infeksi bakteri diperoleh tujuh jenis bakteri yang terdapat di semua rantai perdagangan dan Vibrio alginolyticus merupakan bakteri dominan yang diperoleh dan bersifat patogen. Infeksi virus BCIV terdapat di tingkat pengumpul di Luwuk dengan prevalensi $86,67 \%$ dan di tingkat eksportir di Bali dan Manado masing-masing dengan prevalensi 20\%dan 50\% Berdasarkan hasil tersebut diharapkan pelaku usaha ikan hias dapat mencegah terjadinya infeksi penyakit tersebut agar dapat bersaing dalam pemasaran dengan menghasilkan produk ikan hias Indonesia yang mempunyai kualitas terbaik di dunia.
\end{abstract}

\section{KATA KUNCl: Banggai Cardinal; ikan hias; penyakit infeksi}

ABSTRACT: Diseases infection in Banggai Cardinal (Pterapogon kauderni) in trade chain. By: Devita Tetra Adriany and Isti Koesharyani

\begin{abstract}
Banggai cardinal fish is an ornamental fish endemic to the Banggai Islands, Central Sulawesi. It has been exploited since 1980's. Banggai Cardinal fish has been export to various countries. However, with many cases of infectious diseases such as bacteria and virus Banggai Cardinal I ridovirus (BCIV), the demand for Banggai Cardinal from Indonesia is declining. The purpose of this study is to trace and inventorize the flow of disease infections in the trade chain of ornamental fish from fisherman, to collectors, and exporters. The analysis was done by taking samples of 15 fish from each trade chain. Observations included examination of parasites, fungi, bacteria, and BCIV analysis. The results showed that no parasite and fungus infecting the fish in all trades chains. Seven bacteria species have been indentified from the fish samples from all trades chains and Vibrio alginolyticus was the common pathogenic bacteria species infecting the fish. Infection of BCIV was found in one of collectors' warehouse in Luwuk with the prevalence of $86.67 \%$ and at the exporters in Bali and Manado with the prevalence rate of 20\%and 50\% respectively. Based on the present results, we suggest that exporters must exercise a rigorous prevention program of the disease in order to be able to compete in the ornamental fish world market.
\end{abstract}

\section{KEYWORDS: Banggai Cardinal; ornamental fish; infection diseases}

\footnotetext{
\# Korespondensi: Karantina Ikan Pengendalian Mutu dan Keamanan Hasil Perikanan Kelas II Luwuk Banggai, Sulawesi Tengah. Jl. Trans Toili, Bubung, Luwuk, Banggai, Kabupaten Banggai, Sulawesi Tengah, Jl. Gunung Tompotika No. 20 Luwuk, Kab. Banggai Sulawesi Tengah, Kode Pos 94714, Indonesia. Tel. + 62461324671

E-mail: istisugama@yahoo.com; skiluwukbanggai@gmail.com
} 


\section{PENDAHULUAN}

Ikan Banggai Cardinal (Pterapogon kauderni) merupakan salah satu spesies ikan hias air laut. Nama lokal dari Banggai Cardinal adalah Bebese Tayung (Bahasa Bajo yang artinya ikan kecil di bulu babi) dan capungan (Bahasa Banggai). Banggai Cardinal adalah ikan endemik dan termasuk ikan yang mouth brooder, ikan jantan menjaga anaknya di dalam mulut. Ikan tersebut hidup di perairan laut Kepulauan Banggai, Sulawesi Tengah.

Populasi Banggai Cardinal diperkirakan tinggal 2,4 juta ekor di 17 pulau besar dan 10 pulau kecil di Banggai. Hal ini disebabkan oleh eksploitasi sumberdaya perikanan yang semakin meningkat sehingga terjadi penurunan jumlah dan ukuran ikan hasil tangkapan nelayan (Vagelli, 2002; Vagelli \& Erdmann, 2002; Vagelli, 2005). Ikan Banggai Cardinal mulai dieksploitasi sejak tahun 1980-an. Dipasarkan sebagai ikan hias dari Denpasar dan Jakarta untuk diekspor ke Singapura, Amerika (Hawai dan Florida), dan Perancis. Di Amerika, ikan ini dijual dengan harga tidak kurang dari US\$100 per ekor. Padahal nelayan penangkap menjualnya hanya dengan harga Rp250,00 (US\$ 0,02) per ekor. Pemanfaatannya tidak diatur dengan baik sehingga eksploitasinya terus meningkat seiring dengan meningkatnya permintaan pasar ekspor (Lunn \& Moreau, 2004).

Sejak beberapa waktu lalu, spesies ikan Banggai Cardinal atau Banggai Cardinal Fish (BCF) ini mulai menarik perhatian dunia internasional seiring dengan adanya usulan dari negara Amerika Serikat memasukkannya ke dalam daftar lampiran Convention on the International Trade in Endangered Species (CITES), suatu konvensi yang mengatur perdagangan internasional terhadap spesies flora dan fauna yang terancam punah. Spesies ini berhasil diperjuangkan oleh delegasi Indonesia tidak masuk dalam Apendiks II CITES sehingga dalam pengelolaannya masih mengacu pada prinsip-prinsip pengelolaan perikanan sebagaimana sesuai prinsip Food and Agriculture Organization (FAO). Dengan demikian untuk tujuan pengelolaan perikanan ikan Banggai Cardinal yang berkelanjutan, maka dilakukan Rencana Aksi Banggai Cardinal Fish atau disingkat RPP-BCF (Ndobe et al., 2005).

Banggai Cardinal yang dimanfaatkan sebagai ikan hias, dalam perdagangannya harus terbebas dari infeksi penyakit. Penyakit yang umum ditemukan adalah infeksi parasit, jamur, bakteri, dan virus yang merupakan ancaman bagi Banggai Cardinal. Bakteri yang umum ditemukan adalah dari genus Vibrio yaitu Vibrio alginolyticus dan Vibrio harveyi yang menginfeksi induk atau calon induk, infeksi biasanya terjadi setelah penangkapan dan masa aklimatisasi di bak pemeliharaan, tetapi infeksi terjadi juga di hatcheri dan dapat menyebabkan kematian massal. Infeksi sekunder parasit yang umum ditemukan adalah scutica yaitu Uronema sp. dan Cryptocarion irritans, parasit jenis ini menyerang organ insang sehingga mengakibatkan terganggunya pertukaran oksigen ke dalam insang dan akhirnya menimbulkan kematian ikan. Sedangkan infeksi jamur pada ikan hias ini yang berhasil diisolasi pada media jamur Pepton Yeast Glucose Seawater Agar (PYGSA) diidentifikasi sebagai Lagenidium callinectes (Roza et al., 2009; Setiawati et al., 2011). Informasi, bahwa infeksi iridovirus di Amerika Serikat menyerang Banggai Cardinal dan menyebabkan kematian massal baik di importir maupun hatcheri perbenihan, sehingga menyebabkan kerugian ekonomi yang tidak sedikit (Zamrud, 2012). Kasus infeksi iridovirus ini sesuai dengan penelitian yang dilakukan oleh University of Florida Tropical Aquaculture Laboratory pada tahun 2009-2011 yang menyatakan bahwa ada strain baru dari iridovirus yaitu Banggai Cardinal Iridovirus (BCIV) yang memiliki genus Megalocytivirus (Weber et al., 2009). Mengingat rantai perdagangan Banggai Cardinal sangat kompleks, mulai dari nelayan penangkap hingga konsumen penggemar akuarium air laut dan melibatkan banyak pihak yang sebagian atau seluruh pendapatannya tergantung dari aktivitas tersebut, maka dianggap penting untuk mengetahui penyakit tersebut lebih mendalam. Hingga kini belum ada penelusuran dan inventarisasi penyakit yang menyerang Banggai Cardinal sehingga perlu dilakukan pengamatan penyakit yang menginfeksi ikan Banggai Cardinal dalam rantai perdagangan mulai dari nelayan penangkap, pengumpul, dan eksportir. Tujuan penelitian ini adalah untuk menelusuri dan menginventarisasi kejadian infeksi penyakit pada rantai perdagangan ikan hias Banggai Cardinal sehingga dapat bersaing dalam pemasaran dengan menghasilkan produk ikan hias Indonesia yang mempunyai kualitas terbaik di dunia.

\section{BAHAN DAN METODE}

\section{Koleksi Sampel}

Penelitian dilaksanakan pada tahun 2015, sebanyak 15 ekor sampel ikan Banggai Cardinal (Pterapogon kauderni) diambil dari nelayan penangkap masingmasing dari tiga lokasi yaitu Bone Baru, Tinakin Laut, dan Tolokibit, Sulawesi Tenggara untuk pemeriksaan parasit, jamur, bakteri, dan virus (Gambar 1).

Pengambilan sampel pada tingkat pengumpul hanya dilakukan di satu lokasi Luwuk Banggai, masingmasing dikoleksi sebanyak 15 ekor untuk pemeriksaan parasit, jamur, bakteri, dan virus. Pada tingkat eksportir sampel ikan hias dikumpulkan dari Jakarta dan Bali 


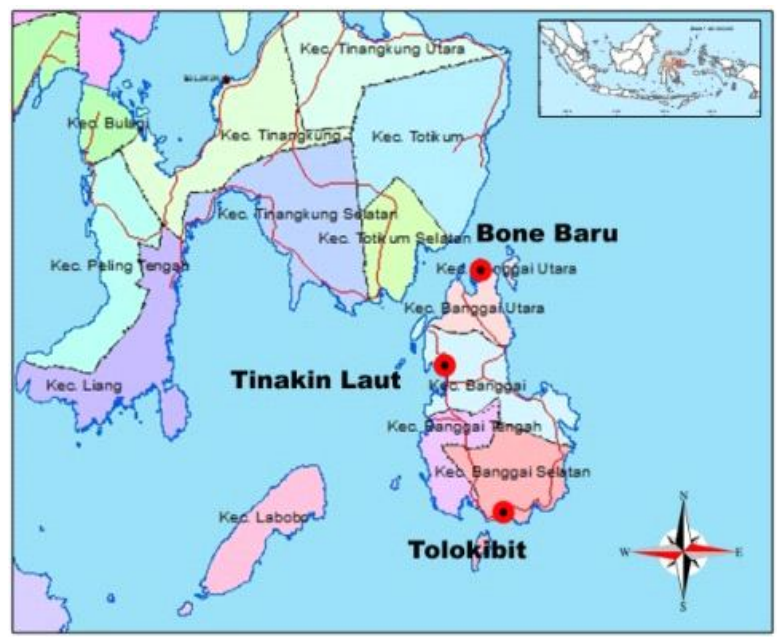

Gambar 1. Lokasi pengambilan sampel ikan dari nelayan penangkap (tanda merah) di Sulawesi Tenggara.

Figure 1. Locations of fish samples colected from fishermen (red marked) in Southeast Sulawesi.

sebanyak 15 ekor untuk analisis parasit, jamur, dan virus, kecuali 10 ekor sampel dari Manado (Tabel 1).

Pemeriksaan parasit, bakteri, jamur dilakukan di Laboratorium Stasiun Karantina Ikan Pengendalian Mutu dan Keamanan Hasil Perikanan Kelas II Luwuk Banggai (Stasiun KIPM-KHP Kelas II Luwuk Banggai), Laboratorium Balai Besar KIPM-KHPJakarta I, dan Balai KIPM-KHP Kelas I Denpasar. Deteksi virus BCIV dilakukan di Laboratorium Kesehatan Ikan Pusat Penelitian dan Pengembangan Perikanan Budidaya, Jakarta dengan metode Polymerase Chain Reaction (PCR). Pengambilan sampel ikan menggunakan metode selektif sampling yaitu berdasarkan ciri-ciri yang menunjukkan gejala klinis sesuai dengan target pemeriksaan penyakit yang ditentukan. Semua sampel ikan diukur panjang total tubuh sebelum dilakukan pemeriksaan penyakit.

\section{Identifikasi Parasit}

Pemeriksaan ektoparasit dilakukan pada organ luar ikan seperti bagian kulit atau permukaan tubuh, sirip, operculum (tutup insang), dan insang. Ektoparasit berukuran makro dengan mudah dapat terlihat secara visual oleh mata atau dengan bantuan kaca pembesar. Pemeriksaan ektoparasit yang berukuran mikro dilakukan dengan menggunakan mikroskop. Tahapan pemeriksaan insang adalah dengan menggunting operculum sehingga insang dapat terlihat dengan jelas. Insang dikeluarkan dan setiap lembar insang dipisahkan, kemudian diletakkan di dalam cawan petri

Tabel 1. Tingkat perdagangan, lokasi, dan jumlah sampel yang diambil dalam pengujian

Tabe 1. The level of trade, location, and number of samples taken in the study

\begin{tabular}{lccccc}
\hline \multirow{2}{*}{$\begin{array}{l}\text { Tingkatan perdagangan } \\
\text { Trade chain }\end{array}$} & \multirow{2}{*}{$\begin{array}{c}\text { Lokasi sampling } \\
\text { Sampling location }\end{array}$} & \multicolumn{4}{c}{ Pengujian (ekor) /Tests (fish) } \\
\cline { 3 - 6 } & Jamur (Fungi) & Parasit (Parasite) Bakteri (Bacteria) Virus (Virus) \\
\hline \multirow{2}{*}{$\begin{array}{l}\text { Penangkap } \\
\text { Fisherman }\end{array}$} & Bone Baru & 15 & 15 & 15 & 15 \\
& Tinakin Laut & 15 & 15 & 15 & 15 \\
\hline Pengumpul & Tolokibit & 15 & 15 & 15 & 15 \\
Collector & Luwuk & 15 & 15 & 15 & 15 \\
\hline \multirow{2}{*}{$\begin{array}{l}\text { Eksportir } \\
\text { Exporters }\end{array}$} & Jakarta & 15 & 15 & 15 & 15 \\
& Bali & 0 & 15 & 15 & 15 \\
\hline & Manado & 0 & 0 & 0 & 10 \\
\hline
\end{tabular}


yang berisi larutan fisiologis dan diamati di bawah mikroskop. Identifikasi parasit dilakukan dengan mengacu pada Kabata (1985).

\section{Identifikasi Jamur}

Jamur diisolasi dari kulit, sirip, dan insang. Isolat kemudian dikultur pada media jamur Potato Dextrose Agar (PDA) dalam cawan petri yang mengandung antibiotik penicillin untuk menghambat pertumbuhan bakteri. Inkubasi dilakukan pada suhu $25^{\circ} \mathrm{C}-30^{\circ} \mathrm{C}$ selama 2-3 hari dan diamati di bawah mikroskop setiap hari. Identifikasi dilakukan dengan mengacu pada Fisher \& Cook (1998).

\section{Identifikasi Bakteri}

Tahapan identifikasi bakteri, sampel ikan dibius terlebih dahulu sebelum ikan dinekropsi dan dilakukan pengamatan patologi anatomi yang terdiri atas pemeriksaan eksternal (sirip, sisik, lendir, kulit, insang) dan pemeriksaan internal (ginjal, limpa, hati). Selanjutnya bagian tubuh eksternal maupun internal yang mengalami perubahan patologi dijadikan sampel untuk isolasi bakteri. Isolat bakteri dari sampel dengan organ target dipotong dan dioleskan pada media umum bakteri untuk ikan air laut yaitu Tryptic Soy Agar (TSA) $2 \% \mathrm{NaCl}$ dan diinkubasi pada suhu $25^{\circ} \mathrm{C}$ selama 24 jam. Koloni bakteri yang tumbuh terpisah dan tampak berbeda warna dan bentuk koloninya selanjutnya dibuat isolat kultur murni. Isolat murni diperoleh melalui purifikasi bertahap 3-4 kali sehingga diperoleh isolat koloni tunggal dari satu jenis bakteri. Setelah diperoleh koloni murni, maka dilakukan uji biokimia terhadap koloni tersebut. Identifikasi bakteri meliputi uji pendahuluan dan uji Ianjutan. Uji pendahuluan merupakan uji biokimia yang terdiri atas uji oksidase, uji katalase, uji motilitas, dan pewarnaan gram. Uji lanjutan terdiri atas uji indol, methyl red (MR), voges proskauer (VP), uji karbohidrat (glukosa, laktosa, maltosa, sukrosa, mannitol, sorbitol, inositol, xylose), nitrat, gelatin, ornitin, urease, citrat, lysin dan oksidatif/ fermentatif (0/F). Identifikasi bakteri dilakukan dengan mengamati karakteristik bakteri berdasarkan pengamatan morfologi koloni, pengujian sifat fisiologis maupun sifat biokimia disusun dalam bentuk tabel, kemudian diidentifikasi berdasarkan Cowan (1974) dan dikonfirmasi dengan Buller (2004) dan Austin \& Austin (2007).

\section{Deteksi Virus}

Deteksi virus dilakukan dengan metode Polymerase Chain Reaction mengikuti metode (Kurita et al., 1998). Adapun tahapan deteksi meliputi: ektraksi DNA dari jaringan target ginjal dan limpa menggunakan kit DNAZol. Amplifikasi dilakukan menggunakan spesifik
Primer RSIV1F: 5'CTCAAACACTCTggCTCATC'3 dan 1R:'5gCACCAACACATCTCCTATC'3, reaksi amplifikasi PCR menggunakan Super Mix Go Green Tag dan genom DNA $2 \mu$ L dengan target berat molekul $570 \mathrm{bp}$. Hasil amplifikasi selanjutnya dielektroforesis pada 1,5\%gel agarose dan pewarnaan dengan ethidium bromida, serta didokumentasikan dengan $\mathrm{Gel}$ doc.

\section{Analisis Data}

Data yang diperoleh disajikan secara tabulasi dan deskriptif dengan terlebih dahulu menghitung prevalensi atau frekuensi kejadian penyakit (PKP). Menurut Dogiel et al. (1970), tingkat prevalensi dapat dihitung dengan rumus sebagai berikut:

$$
\text { PKP }=\frac{\text { Jumlah ikan yang terinfeksi (ekor) }}{\text { Jumlah ikan yang diperiksa (ekor) }} \times 100 \%
$$

\section{HASIL DAN BAHASAN}

Ukuran panjang total tubuh ikan Banggai Cardinal yang digunakan sebagai sampel dalam penelitian ini berukuran $5,65 \pm 0,61 \mathrm{~cm}$ yang berasal dari nelayan penangkap, 5,95 $\pm 0,47 \mathrm{~cm}$ dari pengumpul dan 5,6 $\pm 0,34 \mathrm{~cm}$ dari tingkat eksportir. Hasil pengamatan di nelayan penangkap (tiga lokasi), pengumpul (satu lokasi), dan eksportir (tiga lokasi) tidak ditemukan infeksi jamur maupun parasit. Hasil pemeriksaan di tingkat nelayan penangkap dan pengumpul disajikan pada Tabel 2, 3, dan 4. Hasil pengamatan terhadap infeksi bakteri, ternyata ditemukan di semua tingkat rantai perdagangan. Selanjutnya, hasil analisis karakteristik secara biokimiajenis bakteri tertera pada Tabel 4, sedangkan tingkat prevalensi disajikan pada Gambar 2.

Analisis bakteri di tingkat nelayan penangkap ikan Banggai Cardinal dilakukan pada ikan yang masih hidup untuk menghindari kontaminasi dari bakteri pembusuk atau bakteri yang bukan berasal dari ikan uji. Adapun bakteri yang teridentifikasi pada tingkat nelayan penangkap yaitu Alcaligenes faecalis, Micrococcus luteus, Acinetobacter spp., Plesiomonas shigelloides, Yersinia enterocolitica, dan Vibrio alginolyticus.

Jenis bakteri yang menginfeksi ikan Banggai Cardinal di tingkat pengumpul Luwuk Banggai adalah Vibrio alginolyticus dan P. shigelloides (Gambar 3). Bakteri $V$. alginolyticus merupakan salah satu bakteri patogen yang tergolong dalam famili Vibrionaceae. Bakteri V. alginolyticus merupakan bakteri gram negatif berbentuk batang panjang atau lengkung, berukuran 0,5-2,0 $\mu \mathrm{m}$ dapat bergerak karena mempunyai $2-3$ flagela polar. Strain virulen biasanya menyebabkan wabah penyakit yang berhubungan dengan perubahan lingkungan, stres, perubahan suhu yang mendadak, 
Tabel 2. Hasil pemeriksaan parasit dari tingkat nelayan penangkap di tiga lokasi yang berbeda (Bone Baru, Tinakin Laut, dan Tolokkibit), Sulawesi Tenggara

Tabe 2. Results of parasite examination from fisherman level in three different locations (Bone Baru, Tinakin Laut and Tolokkibit), Southeast Sulawesi

\begin{tabular}{|c|c|c|c|c|c|c|c|c|}
\hline \multicolumn{3}{|c|}{ Bone Baru } & \multicolumn{3}{|c|}{ Tinakin Laut } & \multicolumn{3}{|c|}{ Tolokibit } \\
\hline $\begin{array}{l}\text { Kode sampel } \\
\text { Sample code }\end{array}$ & $\begin{array}{c}\text { Hasil uji } \\
\text { parasit } \\
\text { Parasitic test }\end{array}$ & $\begin{array}{c}\text { Prevalensi } \\
\text { Prevalence } \\
\text { (\%) }\end{array}$ & $\begin{array}{l}\text { Kode sampel } \\
\text { Sample code }\end{array}$ & $\begin{array}{c}\text { Hasil uji } \\
\text { parasit } \\
\text { Parasitic test }\end{array}$ & $\begin{array}{c}\text { Prevalensi } \\
\text { Prevalence } \\
\text { (\%) }\end{array}$ & $\begin{array}{l}\text { Kode sampel } \\
\text { Sample code }\end{array}$ & $\begin{array}{c}\text { Hasil uji } \\
\text { parasit } \\
\text { Parasitic test }\end{array}$ & $\begin{array}{c}\text { Prevalensi } \\
\text { Prevalence } \\
\text { (\%) }\end{array}$ \\
\hline $1 \mathrm{BB}$ & $\begin{array}{l}\text { Negatif } \\
\text { Negative }\end{array}$ & 0 & $1 \mathrm{TL}$ & $\begin{array}{l}\text { Negatif } \\
\text { Negative }\end{array}$ & 0 & $1 \mathrm{TK}$ & $\begin{array}{l}\text { Negatif } \\
\text { Negative }\end{array}$ & 0 \\
\hline $2 \mathrm{BB}$ & $\begin{array}{l}\text { Negatif } \\
\text { Negative }\end{array}$ & 0 & $2 \mathrm{TL}$ & $\begin{array}{l}\text { Negatif } \\
\text { Negative }\end{array}$ & 0 & 2 TK & $\begin{array}{l}\text { Negatif } \\
\text { Negative }\end{array}$ & 0 \\
\hline $3 \mathrm{BB}$ & $\begin{array}{l}\text { Negatif } \\
\text { Negative }\end{array}$ & 0 & $3 \mathrm{TL}$ & $\begin{array}{l}\text { Negatif } \\
\text { Negative }\end{array}$ & 0 & 3 TK & $\begin{array}{l}\text { Negatif } \\
\text { Negative }\end{array}$ & 0 \\
\hline $4 \mathrm{BB}$ & $\begin{array}{l}\text { Negatif } \\
\text { Negative }\end{array}$ & 0 & $4 \mathrm{TL}$ & $\begin{array}{l}\text { Negatif } \\
\text { Negative }\end{array}$ & 0 & 4 TK & $\begin{array}{l}\text { Negatif } \\
\text { Negative }\end{array}$ & 0 \\
\hline $5 \mathrm{BB}$ & $\begin{array}{l}\text { Negatif } \\
\text { Negative }\end{array}$ & 0 & $5 \mathrm{TL}$ & $\begin{array}{l}\text { Negatif } \\
\text { Negative }\end{array}$ & 0 & 5 TK & $\begin{array}{l}\text { Negatif } \\
\text { Negative }\end{array}$ & 0 \\
\hline $6 \mathrm{BB}$ & $\begin{array}{l}\text { Negatif } \\
\text { Negative }\end{array}$ & 0 & $6 \mathrm{TL}$ & $\begin{array}{l}\text { Negatif } \\
\text { Negative }\end{array}$ & 0 & $6 \mathrm{TK}$ & $\begin{array}{l}\text { Negatif } \\
\text { Negative }\end{array}$ & 0 \\
\hline $7 \mathrm{BB}$ & $\begin{array}{l}\text { Negatif } \\
\text { Negative }\end{array}$ & 0 & $7 \mathrm{TL}$ & $\begin{array}{l}\text { Negatif } \\
\text { Negative }\end{array}$ & 0 & 7 TK & $\begin{array}{l}\text { Negatif } \\
\text { Negative }\end{array}$ & 0 \\
\hline $8 \mathrm{BB}$ & $\begin{array}{l}\text { Negatif } \\
\text { Negative }\end{array}$ & 0 & $8 \mathrm{TL}$ & $\begin{array}{l}\text { Negatif } \\
\text { Negative }\end{array}$ & 0 & $8 \mathrm{TK}$ & $\begin{array}{l}\text { Negatif } \\
\text { Negative }\end{array}$ & 0 \\
\hline $9 \mathrm{BB}$ & $\begin{array}{l}\text { Negatif } \\
\text { Negative }\end{array}$ & 0 & $9 \mathrm{TL}$ & $\begin{array}{l}\text { Negatif } \\
\text { Negative }\end{array}$ & 0 & 9 TK & $\begin{array}{l}\text { Negatif } \\
\text { Negative }\end{array}$ & 0 \\
\hline $10 \mathrm{BB}$ & $\begin{array}{l}\text { Negatif } \\
\text { Negative }\end{array}$ & 0 & $10 \mathrm{TL}$ & $\begin{array}{l}\text { Negatif } \\
\text { Negative }\end{array}$ & 0 & $10 \mathrm{TK}$ & $\begin{array}{l}\text { Negatif } \\
\text { Negative }\end{array}$ & 0 \\
\hline $11 \mathrm{BB}$ & $\begin{array}{l}\text { Negatif } \\
\text { Negative }\end{array}$ & 0 & $11 \mathrm{TL}$ & $\begin{array}{l}\text { Negatif } \\
\text { Negative }\end{array}$ & 0 & $11 \mathrm{TK}$ & $\begin{array}{l}\text { Negatif } \\
\text { Negative }\end{array}$ & 0 \\
\hline $12 \mathrm{BB}$ & $\begin{array}{l}\text { Negatif } \\
\text { Negative }\end{array}$ & 0 & $12 \mathrm{TL}$ & $\begin{array}{l}\text { Negatif } \\
\text { Negative }\end{array}$ & 0 & $12 \mathrm{TK}$ & $\begin{array}{l}\text { Negatif } \\
\text { Negative }\end{array}$ & 0 \\
\hline $13 \mathrm{BB}$ & $\begin{array}{l}\text { Negatif } \\
\text { Negative }\end{array}$ & 0 & $13 \mathrm{TL}$ & $\begin{array}{l}\text { Negatif } \\
\text { Negative }\end{array}$ & 0 & $13 \mathrm{TK}$ & $\begin{array}{l}\text { Negatif } \\
\text { Negative }\end{array}$ & 0 \\
\hline $14 \mathrm{BB}$ & $\begin{array}{l}\text { Negatif } \\
\text { Negative }\end{array}$ & 0 & $14 \mathrm{TL}$ & $\begin{array}{l}\text { Negatif } \\
\text { Negative }\end{array}$ & 0 & $14 \mathrm{TK}$ & $\begin{array}{l}\text { Negatif } \\
\text { Negative }\end{array}$ & 0 \\
\hline $15 \mathrm{BB}$ & $\begin{array}{l}\text { Negatif } \\
\text { Negative }\end{array}$ & 0 & $15 \mathrm{TL}$ & $\begin{array}{l}\text { Negatif } \\
\text { Negative }\end{array}$ & 0 & $15 \mathrm{TK}$ & $\begin{array}{l}\text { Negatif } \\
\text { Negative }\end{array}$ & 0 \\
\hline
\end{tabular}

penanganan yang tidak baik, penurunan oksigen, umur ikan, suhu tinggi, kandungan oksigen yang rendah, dan kepadatan populasi (Austin \& Austin, 2007).

Dalam penelitian ini, infeksi bakteri $V$. alginolyticus diperoleh hampir di setiap tingkatan dalam rantai perdagangan ikan hias Banggai Cardinal, karena bakteri ini banyak tersebar di perairan dan umum terdapat baik pada budidaya udang putih Litopenaeus vannamei (Liu et al., 2004) dan budidaya ikan kerapu (Koesharyani et al., 2001).
Hasil analisis dan identifikasi bakteri, ternyata bakteri V. alginolyticus paling banyak menginfeksi Banggai Cardinal di tingkat pengumpul Luwuk Banggai dengan tingkat prevalensi sebanyak 60\%(9/15) dari ikan sampel, sedangkan infeksi P. shigelloides dengan tingkat prevalensi sebanyak 40\%(6/15) dari ikan yang diperiksa (Gambar 3).

Di tingkat pengumpul ikan Banggai Cardinal sangat rentan terhadap kondisi lingkungan yang baru karena 
Tabel 3. Hasil pemeriksaan jamur dari tingkat nelayan penangkap di tiga lokasi yang berbeda (Bone Baru, Tinakin Laut, dan Tolokkibit), Sulawesi Tenggara

Table 3. Results of fungus examination from fisherman level in three different locations (Bone Baru, Tinakin Laut, and Tolokkibit), Southeast Sulawesi

\begin{tabular}{|c|c|c|c|c|c|c|c|c|}
\hline \multicolumn{3}{|c|}{ Bone Baru } & \multicolumn{3}{|c|}{ Tinakin Laut } & \multicolumn{3}{|c|}{ Tolokibit } \\
\hline $\begin{array}{l}\text { Kode sampel } \\
\text { Sample code }\end{array}$ & $\begin{array}{c}\text { Hasil uji } \\
\text { jamur } \\
\text { Fungi test }\end{array}$ & $\begin{array}{c}\text { Prevalensi } \\
\text { Prevalence } \\
(\%)\end{array}$ & $\begin{array}{l}\text { Kode sampel } \\
\text { Sample code }\end{array}$ & $\begin{array}{l}\text { Hasil uji } \\
\text { jamur } \\
\text { Fungi test }\end{array}$ & $\begin{array}{c}\text { Prevalensi } \\
\text { Prevalence } \\
(\%)\end{array}$ & $\begin{array}{l}\text { Kode sampel } \\
\text { Sample code }\end{array}$ & $\begin{array}{c}\text { Hasil uji } \\
\text { jamur } \\
\text { Fungi test }\end{array}$ & $\begin{array}{c}\text { Prevalensi } \\
\text { Prevalence } \\
\text { (\%) }\end{array}$ \\
\hline $1 \mathrm{BB}$ & $\begin{array}{l}\text { Negatif } \\
\text { Negative }\end{array}$ & 0 & $1 \mathrm{TL}$ & $\begin{array}{l}\text { Negatif } \\
\text { Negative }\end{array}$ & 0 & $1 \mathrm{TK}$ & $\begin{array}{l}\text { Negatif } \\
\text { Negative }\end{array}$ & 0 \\
\hline $2 \mathrm{BB}$ & $\begin{array}{l}\text { Negatif } \\
\text { Negative }\end{array}$ & 0 & $2 \mathrm{TL}$ & $\begin{array}{l}\text { Negatif } \\
\text { Negative }\end{array}$ & 0 & 2 TK & $\begin{array}{l}\text { Negatif } \\
\text { Negative }\end{array}$ & 0 \\
\hline $3 \mathrm{BB}$ & $\begin{array}{l}\text { Negatif } \\
\text { Negative }\end{array}$ & 0 & $3 \mathrm{TL}$ & $\begin{array}{l}\text { Negatif } \\
\text { Negative }\end{array}$ & 0 & 3 TK & $\begin{array}{l}\text { Negatif } \\
\text { Negative }\end{array}$ & 0 \\
\hline $4 \mathrm{BB}$ & $\begin{array}{l}\text { Negatif } \\
\text { Negative }\end{array}$ & 0 & $4 \mathrm{TL}$ & $\begin{array}{l}\text { Negatif } \\
\text { Negative }\end{array}$ & 0 & 4 TK & $\begin{array}{l}\text { Negatif } \\
\text { Negative }\end{array}$ & 0 \\
\hline $5 \mathrm{BB}$ & $\begin{array}{l}\text { Negatif } \\
\text { Negative }\end{array}$ & 0 & $5 \mathrm{TL}$ & $\begin{array}{l}\text { Negatif } \\
\text { Negative }\end{array}$ & 0 & 5 TK & $\begin{array}{l}\text { Negatif } \\
\text { Negative }\end{array}$ & 0 \\
\hline $6 \mathrm{BB}$ & $\begin{array}{l}\text { Negatif } \\
\text { Negative }\end{array}$ & 0 & $6 \mathrm{TL}$ & $\begin{array}{l}\text { Negatif } \\
\text { Negative }\end{array}$ & 0 & 6 TK & $\begin{array}{l}\text { Negatif } \\
\text { Negative }\end{array}$ & 0 \\
\hline 7 BB & $\begin{array}{l}\text { Negatif } \\
\text { Negative }\end{array}$ & 0 & $7 \mathrm{TL}$ & $\begin{array}{l}\text { Negatif } \\
\text { Negative }\end{array}$ & 0 & 7 TK & $\begin{array}{l}\text { Negatif } \\
\text { Negative }\end{array}$ & 0 \\
\hline 8 BB & $\begin{array}{l}\text { Negatif } \\
\text { Negative }\end{array}$ & 0 & $8 \mathrm{TL}$ & $\begin{array}{l}\text { Negatif } \\
\text { Negative }\end{array}$ & 0 & 8 TK & $\begin{array}{l}\text { Negatif } \\
\text { Negative }\end{array}$ & 0 \\
\hline $9 \mathrm{BB}$ & $\begin{array}{l}\text { Negatif } \\
\text { Negative }\end{array}$ & 0 & $9 \mathrm{TL}$ & $\begin{array}{l}\text { Negatif } \\
\text { Negative }\end{array}$ & 0 & 9 TK & $\begin{array}{l}\text { Negatif } \\
\text { Negative }\end{array}$ & 0 \\
\hline $10 \mathrm{BB}$ & $\begin{array}{l}\text { Negatif } \\
\text { Negative }\end{array}$ & 0 & $10 \mathrm{TL}$ & $\begin{array}{l}\text { Negatif } \\
\text { Negative }\end{array}$ & 0 & $10 \mathrm{TK}$ & $\begin{array}{l}\text { Negatif } \\
\text { Negative }\end{array}$ & 0 \\
\hline $11 \mathrm{BB}$ & $\begin{array}{l}\text { Negatif } \\
\text { Negative }\end{array}$ & 0 & $11 \mathrm{TL}$ & $\begin{array}{l}\text { Negatif } \\
\text { Negative }\end{array}$ & 0 & $11 \mathrm{TK}$ & $\begin{array}{l}\text { Negatif } \\
\text { Negative }\end{array}$ & 0 \\
\hline $12 \mathrm{BB}$ & $\begin{array}{l}\text { Negatif } \\
\text { Negative }\end{array}$ & 0 & $12 \mathrm{TL}$ & $\begin{array}{l}\text { Negatif } \\
\text { Negative }\end{array}$ & 0 & $12 \mathrm{TK}$ & $\begin{array}{l}\text { Negatif } \\
\text { Negative }\end{array}$ & 0 \\
\hline $13 \mathrm{BB}$ & $\begin{array}{l}\text { Negatif } \\
\text { Negative }\end{array}$ & 0 & $13 \mathrm{TL}$ & $\begin{array}{l}\text { Negatif } \\
\text { Negative }\end{array}$ & 0 & $13 \mathrm{TK}$ & $\begin{array}{l}\text { Negatif } \\
\text { Negative }\end{array}$ & 0 \\
\hline $14 \mathrm{BB}$ & $\begin{array}{l}\text { Negatif } \\
\text { Negative }\end{array}$ & 0 & $14 \mathrm{TL}$ & $\begin{array}{l}\text { Negatif } \\
\text { Negative }\end{array}$ & 0 & 14 TK & $\begin{array}{l}\text { Negatif } \\
\text { Negative }\end{array}$ & 0 \\
\hline $15 \mathrm{BB}$ & $\begin{array}{l}\text { Negatif } \\
\text { Negative }\end{array}$ & 0 & $15 \mathrm{TL}$ & $\begin{array}{l}\text { Negatif } \\
\text { Negative }\end{array}$ & 0 & $15 \mathrm{TK}$ & $\begin{array}{l}\text { Negatif } \\
\text { Negative }\end{array}$ & 0 \\
\hline
\end{tabular}

kondisi ini berbeda dengan kondisi di alam yang menyebabkan ikan menjadi stres sehingga mengakibatkan ikan ini mudah terserang penyakit. Diduga bakteri V. alginolyticus dan P. shigelloides sudah ada dalam lingkungan. Ketika kondisi ikan tidak kondusif pada lingkungan baru, maka bakteri tersebut menginfeksi ikan sehingga menjadi sakit dan bisa menyebabkan kematian jika tidak dilakukan pencegahan. Untuk melakukan pencegahan biasanya digunakan antiseptik seperti iodine karena iodine ini mudah didapat di pasaran dan dapat mempercepat sembuhnya luka. Iodine biasanya diaplikasikan dengan dosis sesuai yang disarankan, dosis $10 \mathrm{mg} / \mathrm{L}$ biasanya digunakan untuk ikan yang baru ditangkap dari alam untuk menekan kematian akibat infeksi bakteri.
Hasil isolasi bakteri yang diperoleh pada ikan Banggai Cardinal di tingkat eksportir Jakarta dan Bali adalah V. alginolyticus dan Vibrio vulnificus dengan tingkat prevalensi yang berbeda. Di tingkat eksportir Jakarta, prevalensi infeksi V. alginolyticus adalah $40 \%$ (6/15) lebih rendah dibandingkan dengan prevalensi infeksi V. alginolyticus di Bali yaitu 60\%(9/15). Di tingkat eksportir Jakarta, prevalensi infeksi bakteri V. vulnificus adalah 53\% (8/15) dan di tingkat eksportir Bali, V. vulnificus prevalensinya sebesar $46,6 \%(7 / 15)$ dari ikan sampel yang diperiksa. Di tingkat eksportir Manado tidak ditemukan infeksi bakteri, hal ini disebabkan karena ikan sampel yang diambil untuk pemeriksaan telah di-treatment dengan antiseptik dan antibiotik untuk menghindari infeksi bakteria. Adapun antiseptik 
Tabel 4. Hasil pemeriksaan jamur dan parasit di tingkat pengumpul Luwuk Banggai Table 4. Results of fungi and parasites examination from collectors in Luwuk Banggai

\begin{tabular}{|c|c|c|c|c|c|}
\hline \multirow{2}{*}{$\begin{array}{l}\text { Kode sampel } \\
\text { Sample code }\end{array}$} & \multirow{2}{*}{$\begin{array}{l}\text { Ukuran } \\
\text { Size (cm) }\end{array}$} & \multirow{2}{*}{$\begin{array}{l}\text { Gejala klinis } \\
\text { Clinical signs }\end{array}$} & \multicolumn{2}{|c|}{ Hasil pemeriksaan (Results test) } & \multirow{2}{*}{$\begin{array}{l}\text { Prevalensi jamur dan parasit } \\
\text { Prevalence fungi and parasite } \\
\text { (\%) }\end{array}$} \\
\hline & & & Jamur (Fungi ) & Parasit (Parasite) & \\
\hline $1 \mathrm{LW}$ & $P=6.0$ & Normal & $\begin{array}{l}\text { Negatif } \\
\text { Negative }\end{array}$ & $\begin{array}{l}\text { Negatif } \\
\text { Negative }\end{array}$ & 0 \\
\hline $2 \mathrm{LW}$ & $P=6.5$ & Normal & $\begin{array}{l}\text { Negatif } \\
\text { Negative }\end{array}$ & $\begin{array}{l}\text { Negatif } \\
\text { Negative }\end{array}$ & 0 \\
\hline $3 \mathrm{LW}$ & $P=6.0$ & Normal & $\begin{array}{l}\text { Negatif } \\
\text { Negative }\end{array}$ & $\begin{array}{l}\text { Negatif } \\
\text { Negative }\end{array}$ & 0 \\
\hline $4 \mathrm{LW}$ & $P=5.5$ & Normal & $\begin{array}{l}\text { Negatif } \\
\text { Negative }\end{array}$ & $\begin{array}{l}\text { Negatif } \\
\text { Negative }\end{array}$ & 0 \\
\hline $5 \mathrm{LW}$ & $P=6.6$ & Normal & $\begin{array}{l}\text { Negatif } \\
\text { Negative }\end{array}$ & $\begin{array}{l}\text { Negatif } \\
\text { Negative }\end{array}$ & 0 \\
\hline $6 \mathrm{LW}$ & $P=6.2$ & Normal & $\begin{array}{l}\text { Negatif } \\
\text { Negative }\end{array}$ & $\begin{array}{l}\text { Negatif } \\
\text { Negative }\end{array}$ & 0 \\
\hline $7 \mathrm{LW}$ & $P=6.2$ & Normal & $\begin{array}{l}\text { Negatif } \\
\text { Negative }\end{array}$ & $\begin{array}{l}\text { Negatif } \\
\text { Negative }\end{array}$ & 0 \\
\hline $8 \mathrm{LW}$ & $P=6.7$ & Normal & $\begin{array}{l}\text { Negatif } \\
\text { Negative }\end{array}$ & $\begin{array}{l}\text { Negatif } \\
\text { Negative }\end{array}$ & 0 \\
\hline $9 \mathrm{LW}$ & $P=6.1$ & Normal & $\begin{array}{l}\text { Negatif } \\
\text { Negative }\end{array}$ & $\begin{array}{l}\text { Negatif } \\
\text { Negative }\end{array}$ & 0 \\
\hline $10 \mathrm{LW}$ & $P=5.6$ & Normal & $\begin{array}{l}\text { Negatif } \\
\text { Negative }\end{array}$ & $\begin{array}{l}\text { Negatif } \\
\text { Negative }\end{array}$ & 0 \\
\hline $11 \mathrm{LW}$ & $P=5.4$ & Normal & $\begin{array}{l}\text { Negatif } \\
\text { Negative }\end{array}$ & $\begin{array}{l}\text { Negatif } \\
\text { Negative }\end{array}$ & 0 \\
\hline $12 \mathrm{LW}$ & $P=5.3$ & Normal & $\begin{array}{l}\text { Negatif } \\
\text { Negative }\end{array}$ & $\begin{array}{l}\text { Negatif } \\
\text { Negative }\end{array}$ & 0 \\
\hline $13 \mathrm{LW}$ & $P=5.4$ & Normal & $\begin{array}{l}\text { Negatif } \\
\text { Negative }\end{array}$ & $\begin{array}{l}\text { Negatif } \\
\text { Negative }\end{array}$ & 0 \\
\hline $14 \mathrm{LW}$ & $P=5.5$ & Normal & $\begin{array}{l}\text { Negatif } \\
\text { Negative }\end{array}$ & $\begin{array}{l}\text { Negatif } \\
\text { Negative }\end{array}$ & 0 \\
\hline $15 \mathrm{LW}$ & $P=6.2$ & Normal & $\begin{array}{l}\text { Negatif } \\
\text { Negative }\end{array}$ & $\begin{array}{l}\text { Negatif } \\
\text { Negative }\end{array}$ & 0 \\
\hline
\end{tabular}

yang digunakan berupa iodine dan antibiotik (oxytetracicline dan chlorampanicol). Jumlah kelimpahan Vibrio umumnya akan meningkat pada musim panas dan tergantung dari kondisi lingkungan air seperti salinitas, suhu, dan konsentrasi plankton (Tamplin, 2001 dalam Haenen et al., 2013). Bakteri V. vulnificus dapat juga ditemukan hidup bebas di air laut dan pada endapan lumpur di dasar laut (Todar, 2008 dalam Haenen et al., 2013). Selain itu, bakteri ini juga ditemukan pada budidaya udang vaname di Cina (Teng et al., 2017). M enurut Haenen et al. (2013), bakteri ini dapat bersifat zoonosis bila melakukan kontak langsung. Hasil pengamatan dan identifikasi terhadap bakteri V. vulnificus menunjukkan bahwa bakteri tersebut menginfeksi Banggai Cardinal di tingkat eksportir Jakarta dan Bali, ini disebabkan adanya perubahan lingkungan, stres, perubahan suhu yang mendadak, penanganan yang tidak sesuai, dan perbedaan kualitas air antara alam, pengumpul, dan eksportir. Oleh karena itu, pencegahan dan pengendalian terhadap infeksi bakteri harus dilakukan secara dini dengan menjaga kualitas air agar tetap stabil atau tetap berada pada kisaran kualitas air yang normal. 
Tabel 5. Karakterisasi bakteri yang diisolasi dari ikan hias Banggai Cardinal dari lokasi tiga tingkat perdagangan, penangkapan, pengumpul, dan eksportir

Table 5. Characterization of bacteria isolated from Banggai Cardinal fish from locations of three levels of trade: capture, collecting, and exporter

\begin{tabular}{|c|c|c|c|c|c|c|c|c|c|c|}
\hline \multirow{2}{*}{$\begin{array}{c}\text { Uji } \\
\text { Determination }\end{array}$} & \multicolumn{7}{|c|}{ Kode (Code) } & \multirow{2}{*}{$\begin{array}{r}\text { Buller } \\
(2004)\end{array}$} & \multirow{2}{*}{$\begin{array}{c}\text { Austin \& } \\
\text { Austin } \\
\text { (2007) }\end{array}$} & \multirow{2}{*}{$\begin{array}{l}\text { Cowan } \\
\text { (1974) }\end{array}$} \\
\hline & PN1 & PN2 & PN3, P1 & PN4 & PN5 & PN6, P1, EXP1 & EXP2 & & & \\
\hline TCBSA & & & & & & & G & G & & \\
\hline TSA 2\% & + & + & + & + & + & + & + & & & \\
\hline \multicolumn{11}{|l|}{ Uji pendahuluan (Preliminary test) } \\
\hline Motilitas/SIM (Motility/SIM) & + & - & + & + & - & + & + & + & + & + \\
\hline Garam/bentuk (Salt/shape) & - & + & - & - & - & - & - & - & & \\
\hline Katalase (Catalase ) $\left(\mathrm{H}_{2} \mathrm{O}_{2}\right)$ & + & + & + & + & + & + & + & + & & \\
\hline Oksidase (Oxidase) & - & & + & + & + & + & + & + & & \\
\hline \multicolumn{11}{|l|}{ Uji biokimia (Biochemical test) } \\
\hline Citrat (SCA) & - & & - & + & + & + & + & + & & \\
\hline Indol medium & & & + & - & & + & + & + & + & + \\
\hline Ornithin decarboxylase & + & & + & & & + & + & & & \\
\hline$M R$ & + & & & & & + & + & + & + & \\
\hline VP & - & - & - & & & & - & - & + & + \\
\hline O/F test & $\mathrm{F}$ & -10 & $\mathrm{~F}$ & - & 0 & $\mathrm{~F}$ & $\mathrm{~F}$ & $\mathrm{~F}$ & $\mathrm{~F}$ & \\
\hline Urase test & + & & & - & & & - & - & & \\
\hline Lysin decarboxylase & - & & + & & & + & + & & & \\
\hline Mc Conkey & & & & + & + & & & & & \\
\hline Malonat & - & & & & & & & & & \\
\hline Gelatin hydrolysis & - & & - & - & & + & + & & & \\
\hline \multicolumn{11}{|l|}{ Uji gula (Sugars test) } \\
\hline Glukosa (Glucosa ) & + & - & + & - & + & + & + & + & & + \\
\hline Sukrosa (Sucrose) & + & - & - & - & & + & - & - & & + \\
\hline Maltosa (Maltose) & + & - & & & + & & + & + & & \\
\hline Laktosa (Lactose) & - & - & + & - & + & - & + & + & & - \\
\hline Sorbitol & + & - & & & & & - & - & & \\
\hline Mannitol & + & - & & & & & - & - & & \\
\hline Inositol & & & + & & & - & - & - & & \\
\hline Xylosa & & - & & - & + & & & & & \\
\hline $\mathrm{KCN}$ & - & & - & + & & & - & & & \\
\hline Nitrat (Nitrate) & & - & + & & & + & + & + & & \\
\hline $\mathrm{H}_{2} \mathrm{~S}$ & & & & & & & - & - & & \\
\hline $\begin{array}{l}\text { 0/129 sensitivitas } \\
\text { 0/129 sensitivity }\end{array}$ & & & & & & & S & $\mathrm{S}$ & & \\
\hline Hasil (Results) & $\begin{array}{c}\text { Yersinia } \\
\text { entero- } \\
\text { colitica }\end{array}$ & $\begin{array}{l}\text { Macro- } \\
\text { coccus } \\
\text { luteus }\end{array}$ & $\begin{array}{l}\text { Plesiomonas } \\
\text { shigelloides }\end{array}$ & $\begin{array}{l}\text { Alcali- } \\
\text { genes } \\
\text { faecalis }\end{array}$ & $\begin{array}{l}\text { Acineto- } \\
\text { bacter sp. }\end{array}$ & $\begin{array}{l}\text { Vibrio } \\
\text { algino- } \\
\text { lyticus }\end{array}$ & $\begin{array}{l}\text { Vibrio } \\
\text { vulni- } \\
\text { ficus }\end{array}$ & & & \\
\hline
\end{tabular}

Keterangan (Note): $\mathrm{PN}=$ penangkap/nelayan (fisherman); $\mathrm{P}=$ pengumpul (collector); $\mathrm{EXP}=$ eksportir (exporter)

Hasil analisis PCR untuk mendeteksi ada tidaknya infeksi virus BCIV pada ikan Banggai Cardinal yang dikoleksi dari pengumpul dan eksportir disajikan pada (Gambar 5). Pada tingkat nelayan penangkap dari 15 sampel ikan Banggai Cardinal yang dianalisis dari tiga lokasi (Bone baru, Tinakin Laut, dan Tolokkibit) Sulawesi Tenggara tidak terdapat infeksi BCIV. Infeksi BCIV terdeteksi pada tingkat pengumpul dengan prevalensi sebanyak $86,67 \%(13 / 15)$ dari sampel yang diperiksa (Gambar 6). 


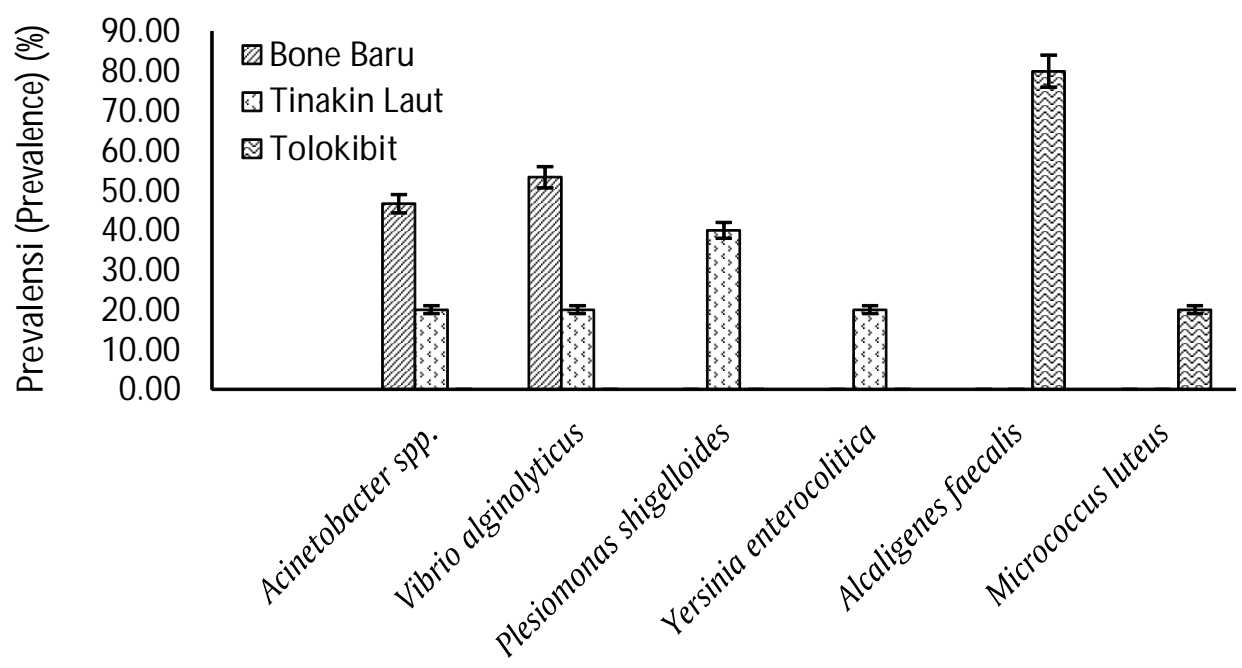

Gambar 2. Jenis dan nilai prevalensi bakteri dari tingkat nelayan penangkap di tiga lokasi (Bone Baru, Tinakin Laut, dan Tolokkibit), Sulawesi Tenggara.

Figure 2. Species and prevalence value of bacteria from fisherman level in three locations (Bone Baru, Tinakin Laut, and Tolokkibit), Southeast Sulawesi.

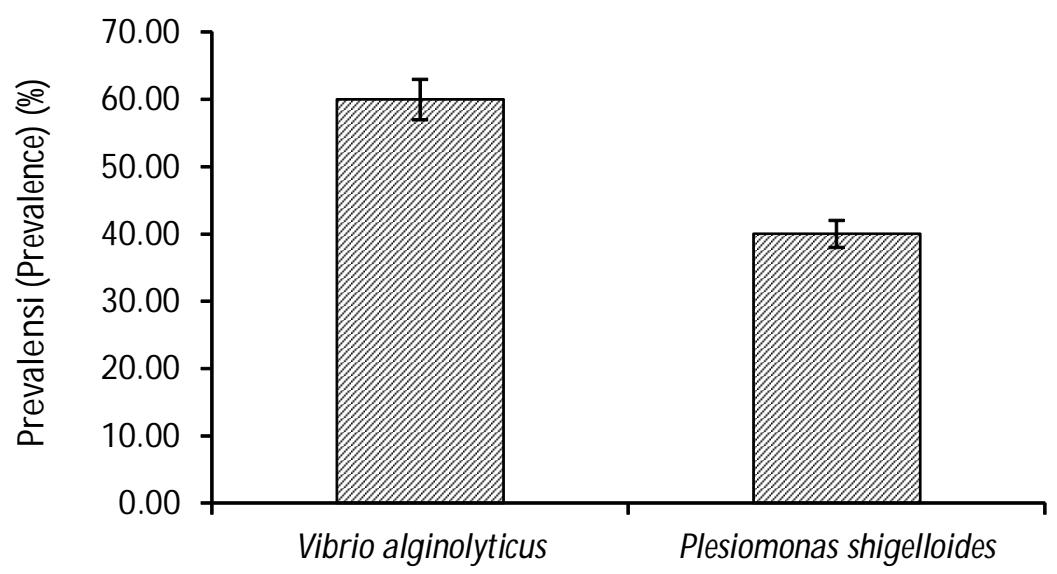

Gambar 3. Nilai prevalensi infeksi bakteri V. alginolyticus $(60 \%)$ dan P. shigelloides $(40 \%)$ dari ikan Banggai Cardinal pada tingkat pengumpul di Luwuk Banggai.

Figure 3. Prevalence value of bacteria infection $\mathbf{V}$. alginolyticus (60\%) and $\mathbf{P}$. shigelloides $(40 \%)$ in Banggai Cardinal fish from colector level in Luwuk Banggai.

Prevalensi infeksi BCIV tersebut yang tertinggi terdapat di tingkat pengumpul Luwuk Banggai. Hal ini disebabkan karena beberapa faktor, di antaranya adalah kualitas air, pemberian pakan, penanganan/handling, pengepakan/packing, keterbatasan ketersediaan tenaga teknis yang kompeten, serta sarana dan prasarana. Akibat dari beberapa faktor tersebut, ikan mengalami stres dan timbul infeksi Banggai Cardinal Iridovirus (BCIV).
Hasil analisis Iridovirus (BCIV) menunjukkan bahwa virus tersebut juga menginfeksi ikan Banggai Cardinal di tingkat eksportir Bali dan Manado dengan prevalensi masing-masing sebesar 20\%(3/15) dan 50\% (5/10) ekor dari ikan yang diperiksa, seperti tertera pada Gambar 7.

Beberapa faktor yang menyebabkan terjadiya infeksi (BCIV) adalah adanya cekaman lingkungan akibat efek transportasi dari pengumpul ke eksportir, serta 


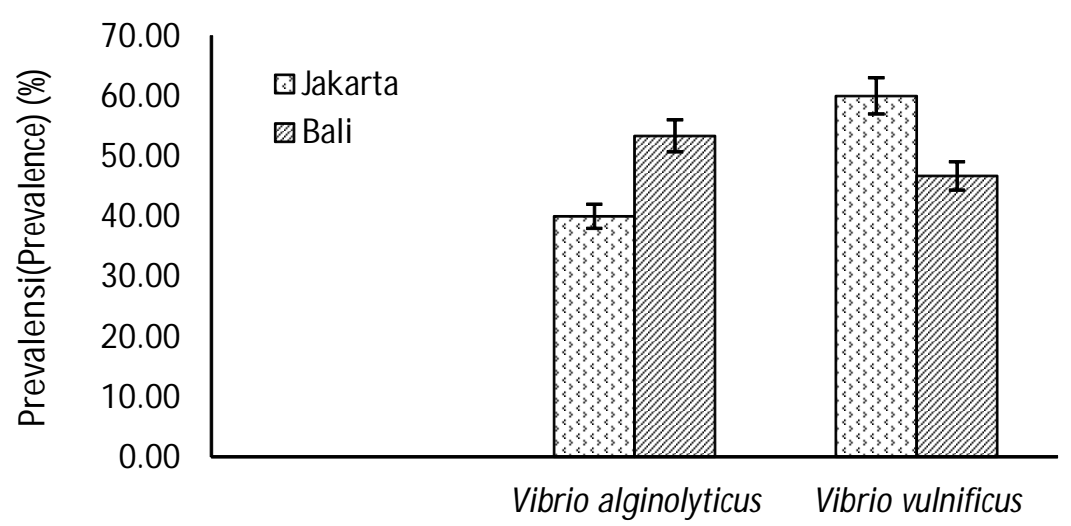

Gambar 4. Nilai prevalensi infeksi bakteri V. alginoliticus dan V. vulnificus dari ikan Banggai Cardinal pada tingkat eksportir di Jakarta dan Bali.

Figure 4. Prevalence value of bacteria infection V. alginoliticus and V. vulnificus from Banggai cardinal fish exporters in Jakarta and Bali. $\begin{array}{llllllll}1 & 2 & 3 & 4 & 5 & (-) & (+) & M\end{array}$

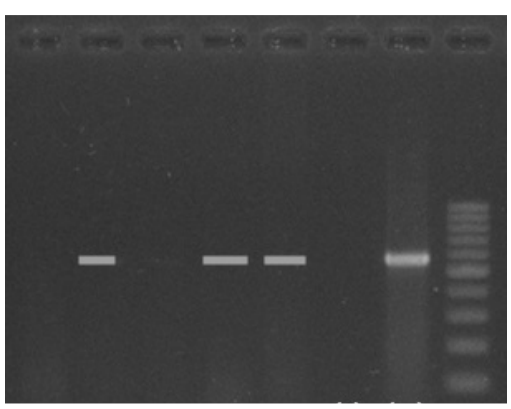

Gambar 5. Pola pita DNA hasil amplifikasi PCR dari ikan Banggai Cardinal yang terinfeksi BCIV pada tingkat pengumpul dan eksportir (Keterangan: (M) 100 bp DNA ladder marker; ikan sampel no. 1, 2, 3, 4, 5; (-) kontrol negatif; (+) kontrol positif).

Figure 5. Pattern of DNA band of PCR product for Banggai Cardinal fish samples infecteted by BCIV from collector and exporters. (Notes: (M) 100 bp DNA ladder marker; sample no. 1, 2, 3, 4, 5; (-) control negative; (+ ) control positive).

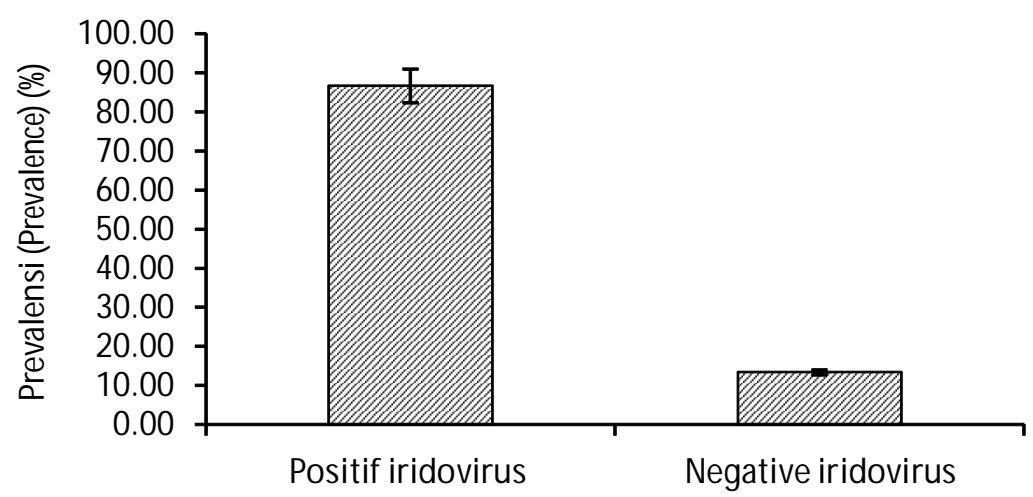

Gambar 6. Nilai prevalensi infeksi Banggai Cardinal Iridovirus (BCIV) pada pengumpul ikan Banggai Cardinal di Luwuk.

Figure 6. Prevalence value of Banggai Cardinal Irido Virus (BCIV) infecting Banggai Cardinal fish from collector level in Luwuk. 


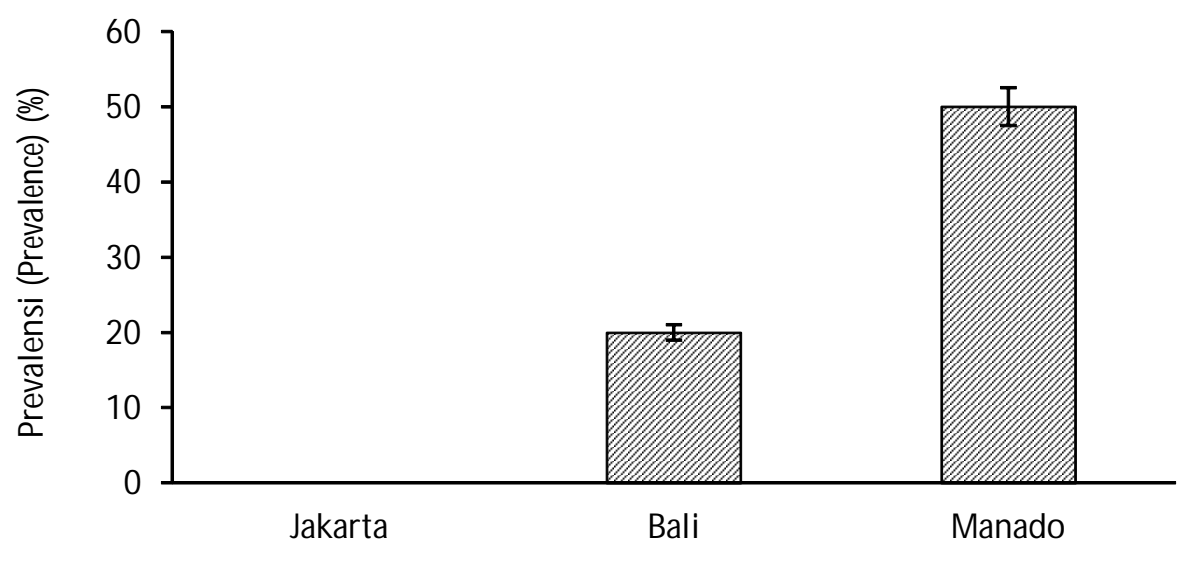

Eksportir (Exporters)

Gambar 7. Nilai prevalensi Banggai Cardinal Iridovirus (BCIV) dari ikan Banggai Cardinal pada eksportir di Jakarta, Bali, dan Manado.

Figure 7. Prevalence value of Banggai Cardinal Iridovirus (BCIV) infecting Banggai Cardinal fish from exporters in Jakarta, Bali, and Manado.

kondisi lingkungan pemeliharaan yang berbeda antara pengumpul dan eksportir. Tetapi sarana dan prasarana, serta penanganan/handling di tingkat eksportir sudah memadai, sehingga persentase kejadian penyakit tidak setinggi di tingkat pengumpul.

Infeksi iridovirus juga banyak terjadi pada budidaya ikan laut seperti kerapu dan kakap (Koesharyani et al., 2001; Mahardika et al., 2003) selain itu, juga ditemukan pada ikan air tawar gurami Osphronemus goramy Lac. (Koesharyani \& Gardenia, 2013). Selain pada ikan hias Banggai Cardinal penyakit ini juga menginfeksi pada ikan hias air tawar dwarf gourami Colisa lalia, ikan angelfish Pterophyllum spp., ikan hias dari golongan cichlids (Koesharyani et al., 2009; Verena et al., 2016; Yanong \& Waltzek, 2013).

\section{KESIMPULAN}

Infeksi bakteri ditemukan pada semua tingkat rantai perdagangan ikan hias Banggai Cardinal tetapi sebaliknya infeksi jamur dan parasit tidak ditemukan. Prevalensi infeksi BCIV terjadi di tingkat pengumpul di Luwuk Banggai dengan prevalensi $86,67 \%$ di tingkat eksportir di Bali dengan prevalensi 20\%dan Manado dengan prevalensi $50 \%$

\section{UCAPAN TERIMA KASIH}

Terima kasih disampaikan Kepada Bapak Prof. Ketut Sugama, M.Sc., Ph.D. dan Bapak Dr. Tb. Haeru Rahayu, M.Sc. yang telah banyak memberi saran dalam penelitian dan penyusunan naskah publikasi ini.

\section{DAFTAR ACUAN}

Austin, B. \& Austin, D.A. (2007). Bacterial fish pathogen: Disease of farmed and wild fish. Fourth Edition. New York, London: Springer Dordrecht Heidelberg.

Buller, N.B. (2004). Bacteria from fish and other aquatic animals: A practical identification manual. London, UK: British Library.

Cowan, S.T. (1974). Manual for the identification of medical bacteria. Second Edition. Press Syndicate of the University of Cambridge.

Dogiel, V.A.G., Petrushevski, G.K., \& Polyanski, I. (1970). Parasitology of Fishes. Hongkong: T.F.H Publisher.

Fisher F. \& Cook, N.B. (1998). Fundamental of diagnostic mycology. Curtis Center Independence Square wet Philadelphia.

Haenen, O.L.M., Evans, J.J., \& Berthe, F. (2013). Bacterial infections from aquatic species: potential for and prevention of contact zoonoses. Rev. Sci. Tech. Off. Int. Epiz., 32(2), 497-507.

Kabata, Z. (1985). Parasites and diseases of fish cultured in the tropics. Canada: Pacific Biological Station Nanaimo. British Columbia.

Kurita, J., Nakajima, K., Hirono, I., \& Aoki, T. (1998). Polymerase Chain Reaction (PCR) amplification of DNA of Red Sea Bream Iridovirus (RSIV). Fish Pathology, 33(1), 17-23.

Koesharyani, I., Roza, D., Mahardika, K., Jhon, F., Zafran, \& Yuasa, K. (2001). Penuntun diagnosa 
penyakit ikan II. Penyakit Ikan Laut dan Krustase di Indonesia. Gondol, Bali.

Koesharyani, I., Santika, A., Zainun, Z., Suhendra, A., Jaelani, Maskur, \& Novita, H. (2009). Infeksi iridovirus pada ikan hias air tawar dwarf gourami (Colisa lalia) di Indonesia. Prosiding Forum Inovasi Teknologi Akuakultur. Jakarta

Koesharyani, I. \& Gardenia, L. (2013). New megalocytivirus infected to the cultured fresh water giant gourami, Ospronemus gouramy Lac. in Indonesia. Indonesian Aquaculture Journal, 8(1), 9399. ISSN 0215-0883. Acreditation Number: 389/ AUP/P2MI-LIPI/04/2012.

Liu, C.-H., Cheng, W., Hsu, J.-P., \& Chen, J.-C. (2004). Vibrio alginolyticus infection in the white shrimp Litopenaeus vannamei confirmed by polymerase chain reaction and 165 rDNA sequencing. Diseases of Aquatic Organisms, 61, 169-174.

Lunn, K. \& Moreau, M. (2004). Unmonitored trade in marine ornamental fishes: the case of Indonesia's Banggai Cardinal (Pterapogon kauderni). Coral Reefs.

Mahardika, K., Koesharyani, I., Prijono, A., \& Yuasa, K. (2003). Infeksi iridovirus pada induk kerapu lumpur (Epinephelus coioides). Jurnal Penelitian Perikanan Indonesia, 9(1), 49-54.

Ndobe, S., Moore, A., \& Supu, A. (2005). The Indonesian ornamental fish trade: case studies and options for improving livelihoods while promoting sustainability, banggai case study final report to NACA. Palu, Indonesia: Yayasan Penyu Hijau.

Roza, D., Johnny, F., \& Setiawati, K.M. (2009). Kasus kematian massal benih ikan capungan Banggai, Pterapogon kauderni di panti benih. Prosiding Forum Inovasi Teknologi Akuakultur, Buku 2, 1027-1033.

Setiawati, K.M., Jhon, H.H., Gunawan, Wardoyo, \& Nyoman, A.G. (2011). Petunjuk teknis perbenihan ikan hias capungan Banggai (Pterapogon kauderni). Balai Besar Penelitian dan Pengenmbangan Budidaya Laut. Singaraja, Bali.
Teng, T., Liang, L., Chen, K., Xi, B., Xie, J., \& Xu, P. (2017). Isolation, identification and phenotypic and molecular characterization of pathogenic Vibrio vulnificus isolated from Litopenaeus vannamei. PloS ONE, 12(10), e0186135. https://doi.org/10.1371/ journal.pone. 0186135 .

Vagelli, A.A. (2002). Notes on the biology, geographic distribution and conservation status of the Banggai Cardinal Pterapogon kauderni Koumans 1933, with comments on captive breeding techniques. Trop: Fish Hobb.

Vagelli, A.A. \& Erdmann, M.V. (2002). First comprehensive ecological survey of the Banggai Cardinal fish, Pterapogon kauderni. Env. Biol. Fish.

Vagelli, A.A. (2005). The Banggai conservation project. Working for the creation of a network of small marine sanctuaries in the Banggai Archipelago, Indonesia. Communique. Am. Zoo \& Aquarium Assoc. 2005.

Verena, J-S., Mikolaj, A., Peter, W., Jan, W., Helmut, We., \& Dieter, S. (2016). First outbreak of an infection with infectious spleenand kidney necrosis virus (ISKNV) in ornamental fish in Germany. Diseases Of Aquatic Organisms, 119, 239-244. doi: 10.3354/dao02995.

Weber, E.S., Waltzek, T.B., Young, D.A., Twitchell, E.L., Gates, A.E., Vagelli, A., Risatti, G.R., Hedrick, R.P., \& Frasca, S.Jr. (2009). Systemic iridovirus infection in the Banggai Cardinal fish (Pterapogon kauderni Koumans 1933). J. Vet. Diagn. Invest., 21, 306-320.

Yanong, R.P.E. \& Waltzek, T.B. (2013). Megalocytivirus infections in fish, with emphasis on ornamental species. UF/IFAS Extension FA182. University of Florida, Gainesville.

Zamrud, M. (2012). Ekspedisi Banggai Cardinal rescue project di Kabupaten Banggai Kepulauan. Jakarta. Diakses pada tanggal 23 M aret 2013. http:/ /www.bkipm.kkp.go.id/bkipm/event/read/838/ ekspedisi-banggai-rescue-project-di-kabupatenbanggai-kepulauan.html 